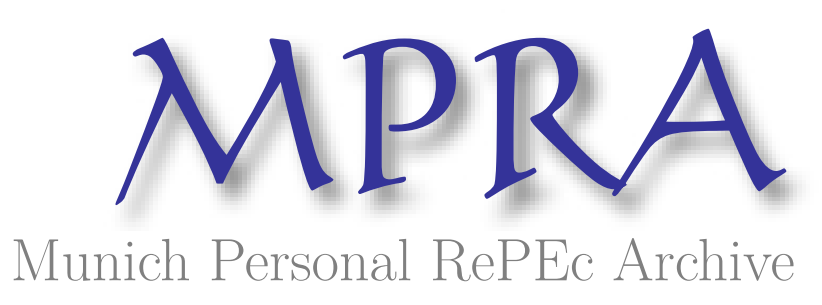

\title{
Trade Union Priorities and Wage Rigidity
}

Drakopoulos, Stavros A.

University of Aberdeen

May 1994

Online at https://mpra.ub.uni-muenchen.de/35791/

MPRA Paper No. 35791, posted 07 Jan 2012 19:25 UTC 


\title{
TRADE UNION PRIORITIES AND WAGE RIGIDITY
}

May 1994

\author{
DR S.A. DRAKOPOULOS \\ LECTURER IN ECONOMICS \\ UNIVERSITY OF ABERDEEN \\ ABERDEEN AB9 2TY \\ U.K
}

\begin{abstract}
The starting point of the paper is that trade unions engage in substitution once certain targets have been met. This implies that a priority-based or hierarchical model might be a better approximation to union behaviour. This model requires a two-part union utility function which changes when a satisfactory (or target) level of the priority variable (e.g. the wage rate) is met. After demonstrating the workings of such a model in a monopoly union framework, it is shown that when the wage is below the target level, there is real wage rigidity. Employment increases only when the target wage has been achieved.
\end{abstract}

Acknowledgements are due to Professors P. Sloane and A. Oswald, Dr Sheila Dow and also to an anonymous referee of this Journal. 


\section{TRADE UNION PRIORITIES AND WAGE RIGIDITY}

\section{Introduction}

The essence of hierarchical or priority based models is that preferences are ordered in the sense that most important or urgent preferences must reach some satisfactory levels before the secondary ones are considered. This implies that substitution among objectives might not be continuous. The idea is not new economics. One can even find it in the work of the nineteenth century economist $\mathrm{C}$. Menger and also in the work of subsequent economists like Little (1957), and Georgescu-Roegen (1966). It is also not unknown in other social sciences like psychology and sociology. In particular, Maslow's theory of needs is the prime example (Maslow,1954). Moreover, hierarchical models have been employed in other branches of economics such as consumer behaviour theory and the theory of the firm (e.g. Ferguson,1965; Encarnacion,1964). However, there has been very little attempt to apply it in analysing trade union behaviour. The idea that the secondary objectives are satisfied only when the most important ones reach some acceptable target levels seems highly appropriate in approximating the behaviour of union organizations with many, and often conflicting, objectives. Such an approach is consistent with the views of authors such as Ross who regard trade unions as extremely complex organizations characterized by economic, political and social goals.

Thus the purpose of this paper is to provide some insights concerning the effects of adopting a priority-based model in a trade union framework. The paper starts with a brief review of the standard approach towards union utility. Subsequently, the basic characteristics of a general priority-based model as applied to union utility are discussed. Furthermore, a simple model of a union with two objectives and which is characterized by priority-based or hierarchical behaviour is examined. The analysis is conducted in a monopoly union framework. 


\section{Standard Formulations of Union Behaviour}

The usual representation of union preferences is of an one part, increasing quasi-concave union utility function which can be derived from the assumptions that 1) all union members are risk averse and 2) that the union has utilitarian preferences. Thus convex union indifference curves are derived which imply that there is continuous substitutability between the two standard variables, wages (w) and employment (n) (Oswald, 1982). Although as we shall discuss, not all theorists accept the above, many authors such as Akerlof (1969) Atherton (1973), Corden (1981), Mulvey (1978), Oswald (1982, 1985) and Rees (1977) have used such an assumption. Other authors use as a general start a Stone-Geary utility function, but the vast majority of them eventually derive the standard smooth union indifference curves. The essence of implicit substitutability in terms of preference comparison can be seen in the following formulation :

Suppose that we have union objectives represented by the vectors ( $\mathrm{P}$ means preferred to):

$$
\begin{aligned}
& \left(w_{1}, n_{1}\right) \text { and }\left(w_{2}, n_{2}\right) \text { and that } \\
& \left(w_{1}, n_{1}\right) P\left(w_{2}, n_{2}\right)
\end{aligned}
$$

The assumption of continuous substitutability implies that there is $a w>w_{2}$ for which

$$
\left(w, n_{2}\right) P\left(w_{1}, n_{1}\right)
$$

This type of preferences is sometimes called Archimedian in the theory of choice (Borch, 1968). In short, Archimedian preferences imply that the union engages in continuous substitution among objectives.

However, there have been theoretical studies which cast doubt on the idea of a continuous substitutability between employment and wages or among union objectives in general. One of the first of such studies was conducted by A. Ross who had serious reservations about the wage-employment trade-off relationship. Ross's approach is more complex and 
connects union behaviour with considerations such as the proportion of labour costs to total costs, the competitiveness of the industry and the level of unionization of the industry (Ross, 1950). Furthermore, Ross argues that unions are not so much concerned with the maximum possible wage increase, as with relative as opposed to absolute wages. (This idea can also be connected to Keynes' point that relativities matter, Ross, 1948.) Ross's idea that unions attempt to enforce the common rule of "equal pay for equal work" has also found support among subsequent theorists (see for instance King, 1990). In the same spirit, Reder doubts the established view that unions maximize in the sense of consumer or the theory of the firm. Instead, he is inclined towards the satisficing model (Reder, 1952, 1960). These ideas suggest that unions might consider certain levels of pay and employment as essential before they undertake substitution.

The notion of the continuous substitutability between employment and wages has also been questioned by other theorists. Cartter for instance states :

"it would seem most likely, once a union is already enjoying a particular wageemployment combination, that it would take a considerable increase in wages to compensate for a reduction in employment, and it would take a considerable increase in employment to compensate for a wage reduction (Cartter, 1959).

The reason for the limited substitutability according to Cartter is mainly the internal political structures and pressures of the union (Cartter, 1959; Mayhew and Turnbull, 1989, Atherton, 1973).

More recently some theorists have suggested that the very practice of focusing solely on wages and employment is also questionable. Instead they suggest that unions are confronted with organizing and representing the entire spectrum of needs that union members experience (Turnbull, 1988). This approach also undermines the idea of continuous substitutability of wages and employment since it brings on the surface a variety of conflicting union objectives (some of them not quantifiable) which need to be satisfied. Faced with conflicting objectives and a variety of members' needs, the union might have limited room for substitution. A connection can be made here with Simon's (1982) concept 
of bounded rationality which is more appropriate when choice (in this case union choice) involves a number of variables.

The above ideas can be interpreted as suggesting that union behaviour cannot be adequately described by the assumption of continuous substitutability among objectives. Instead, the idea of limited substitutability which can best be represented with some type of hierarchical behaviour is more appropriate. In particular, hierarchical behaviour in this context implies that the union would wish to achieve certain levels of some objectives first before starting considering substitution; eg. a certain level of wage increase (depending on which objective is regarded as the most important) or a certain level of membership before engaging in substitution. In other words, after a "satisficing" level is achieved, the union would be prepared to substitute among objectives. Although hierarchical formulations have been proposed, (e.g. Ferguson, 1965, Georgescu-Roegen, 1966 Encarnacion, 1964b, Ironmonger, 1972, Day and Robinson, 1973, Canterbery, 1979, Earl, 1983, Drakopoulos, 1992) they have generally not received attention in connection to union behaviour.

In essence Ross's conception of the union is not that alien to the spirit of the hierarchical formulation. For instance, King supports the view that Ross's ideas correspond more closely to Simon's satisficing theory which is quite close to hierarchical behaviour (King, 1990 and Simon, 1982). Furthermore, some theorists seem to favour a type of hierarchical formulation when they formulate models of strikes. For instance, Ashenfelter and Johns and Swint and Nelson employ the idea that union leadership is interested in providing "some acceptable level of members benefits first" which is quite close to the suggested approach (Ashenfelter and Johnson, 1969, Swint and Nelson, 1978, 1980).

The idea that the complexity of union behaviour cannot be adequately described by the standard approach, has started to gain ground even in the mainstream union literature. For instance, some theorists have realized that the issue of insiders-outsiders requires a two part union utility function. In some modern formulations, the union utility changes when a 
certain level of employment is achieved. The important implication of this specification is that employment is the primary objective up to a certain level. The resulting union indifference curves have a kink point (see Carruth and Oswald, 1987 and Jones and McKenna,1989). It is clear that this approach is not very far from the proposed priority based model.

\section{Formulation of Priority Based Union Utility}

Starting from the general case that the union has a number of objectives, its behaviour may be described by the following hierarchical formulation. Assume that each objective $i$ has a variable $z_{i}$ which corresponds to it. Also assume that the numbering:

$z_{1}, z_{2}, \ldots ., z_{n}$

is such that the problem of the union is the following:

$\max z_{n}$

s.t.

$z_{i} \geq z_{i}^{*}(i=1,2, \ldots ., n-1)$

the $z_{i}^{*}$ is a constant and represents satisfactory levels of corresponding variables. If the above problem has not solution, then the problem becomes:

$\max z_{n-1}$

s.t.

$z_{i} \geq z_{i}^{*}(i=1,2, \ldots ., n-2)$

In other words the least important objective is dropped. If the above has no solution one works similarly until a feasible problem is determined, all lower ordered objectives are 
discarded en route.

We can express this general case in the utility terms. Let

$$
\mathrm{u}_{1}=\mathrm{u}_{1}(\mathrm{z})
$$

be a function which orders alternatives $z$ according to the first objective. Fixing arbitrarily the functions $\mathrm{u}_{1}(\mathrm{z})$, there is a unique vector associated with each $\mathrm{z}$ which might be called utility vector

$$
\left[u_{1}(z), u_{2}(z), \ldots, u_{n}(z)\right]
$$

the union's utility function can be defined in terms of such vectors. Also we have a constant ui* such that when

$$
u_{i}(z)=u_{i}{ }^{*}
$$

z satisfies objective i.

Given the above let us compare two utility vectors:

$$
\begin{aligned}
& {\left[u_{1}(z), u_{2}(z), \ldots, u(z)\right]=u(z)} \\
& {\left[u_{1}\left(z^{\prime}\right), u_{2}\left(z^{\prime}\right), \ldots, u\left(z^{\prime}\right)\right]=u\left(z^{\prime}\right)}
\end{aligned}
$$

then

$$
u(z)>u\left(z^{\prime}\right) \text { iff }
$$

either 1) $u_{1}\left(z^{\prime}\right)<u_{1}(z)<u_{1}^{*}$

or

2) $u_{1}(z)=u_{1}\left(z^{\prime}\right)<u_{1}{ }^{*} ; u_{2}\left(z^{\prime}\right)<u_{2}(z)$

or
3) $\mathrm{u}_{1}{ }^{*}<\mathrm{u}_{1}\left(\mathrm{z}^{\prime}\right), \mathrm{u}_{1}(\mathrm{z})$; $\mathrm{u}_{2}\left(\mathrm{z}^{\prime}\right)<\mathrm{u}_{2}(\mathrm{z})<\mathrm{u}_{2}{ }^{*}$ 
Thus there is a hierarchical ordering of vectors. Once the more important objectives are satisfied the next most important ones become relevant. (For a technical discussion of hierarchy, utility and the types of hierarchical behaviour see Encarnacion, 1964a).

The above ideas can be applied to a simple framework of a union utility with two objectives: wages ( $w$ ) and employment ( $n$ ). Let us assume that the union has a target wage level and that this is its primary objective. There are a number of reasons for adopting the idea of a target wage. First, one might connect the target wage rate to the previous period wage rate. The underlying point here is the Keynesian view that wage cuts are not acceptable. One might also think of a union which has as its first concern to achieve an appropriate wage rate by taking into account the rest of the industry's wage or the national wages. The idea of comparing wage levels has been used by Summers (1988) in his relative wage-based efficiency wage theory. Another justification might lie in the "fair wage" literature (see Akerlof and Yellen,1990).

One can also a make a connection with work on union centralization (see for instance Calmfors and Driffill, 1988). More specifically, the idea of target wage is more compatible with a relatively centralized bargaining framework. In a centralized wage bargaining framework, the idea of a wage target as first priority is more relevant. The union will be very concerned to reach a wage level which is compatible with wages reached in national wage bargaining agreements (Flanagan, Moene and Wallerstein, 1993). Thus the target wage can be linked with national or industry wage settlements. In other words, it is more likely that the union will exhibit priority-based behaviour towards the wage in a more centralized economic environment. Conversely, if wage bargaining is done at the individual firm's level (thus in a decentralized framework), the traditional model in which the union continuously substitutes between employment and wages, seems to be more applicable.

With all the above in mind, let us call the target wage rate $\mathbf{w}^{*}$. The easiest way to 
represent the priority-based model is by constructing a general two-part union utility function:

$$
\begin{aligned}
& U(w, n)=\left\{U_{1}(w, n), U_{2}(w, n)\right\} \\
& \text { where } U(w, n)=U_{1} \quad \text { for } w<w^{*} \\
& \text { and } U(w, n)=U_{2} \quad \text { for } w>w^{*}
\end{aligned}
$$

Having in mind the above, let us give a specific example of a very simple situation where the union members have two objectives: wages and employment $(w, n)$ and where the wage level is the primary target up to a given level $\mathrm{w}^{*}$. When $\mathrm{w}^{*}$ is reached then the union turns its attention to the secondary objective, employment. In order to keep the analysis simple let us assume that union members are identical, that the outside opportunity is zero and that membership is unrestricted. Furthermore, we restrict our discussion to an interior solution which implies that membership is always higher than employment. The two-part union utility function is specified as follows:

wn for $\quad w \leq w^{*}$

$\mathrm{U}=$

$$
q\left(w-w^{*}\right) n+w^{*} n \quad \text { for } \quad w>w^{*}
$$

Where $\mathrm{w}$ is the wage rate, $\mathrm{n}$ is employment and $\mathrm{q}$ is a constant and $\mathrm{O} \leq \mathrm{q} \leq 1$. The first part of the utility function can also be viewed in terms of work sharing: initially the union maximizes the wage bill and distributes it to its members (this can be linked to our previous assumptions, see also Dreze, 1987). The second part of the utility function implies that when the wage exceeds the target or the aspired level then it becomes a secondary objective but it still provides positive utility to the union. The slope of the indifference curve is: 


$$
\begin{gathered}
w \\
--<0 \\
n
\end{gathered} \quad \text { for } w<w^{*}
$$

$d w$

$--=$

dn

$$
\frac{-\left(q w-q w^{*}+w^{*}\right)}{-q n} \text { for } w>w^{*}
$$

It is not hard to see that the union indifference curve will be kinked and negatively sloped. Only when $q=1$ the two slopes will be equal and thus there will be no kink. After checking for convexity, we can also see that in the region close to $w^{*}$ we have:

$$
\begin{aligned}
& d w \quad d w \\
& \left.\overline{d n} \quad \lim w_{-}\right) w^{*}-\quad>\begin{array}{cc}
-- & \\
d n & \left.\lim w_{-}\right) w^{*}+
\end{array}
\end{aligned}
$$

Therefore the resulting indifference curve will have a kink at $\mathbf{w}^{*}$.

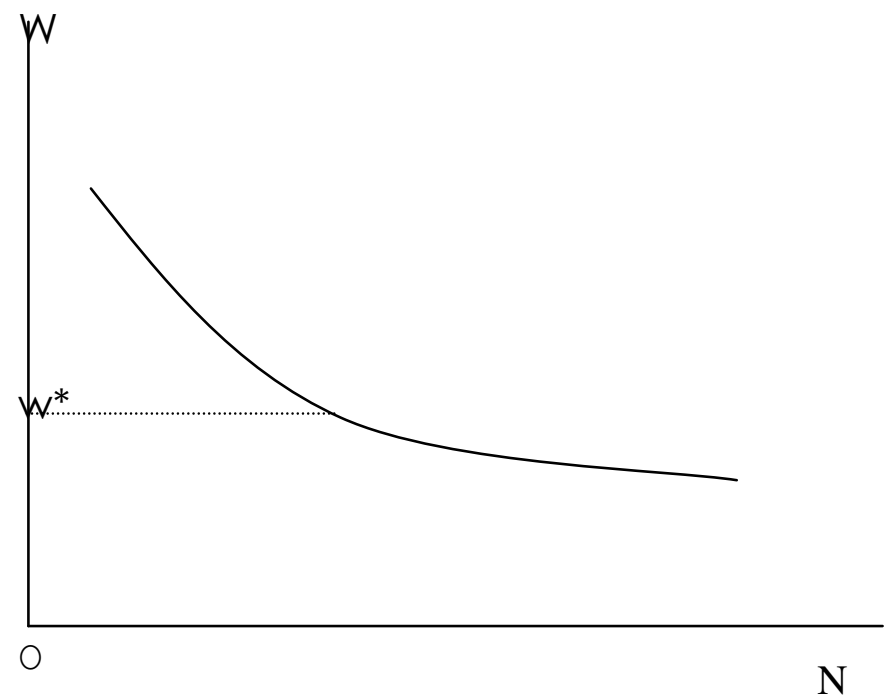

Figure 1: The kinked union indifference curve 
Thus the priority-based approach gives kinked union indifference curves, and this is in contrast to the smooth curves implied by the standard theory.

\section{Some Implications in a Monopoly Union Model}

We make the standard assumption that we operate in the context of a Monopoly Union model (McDonald and Solow, 1981; Oswald, 1982, Mayhew and Turnbull, 1989). This model implies that firm sets $\mathrm{n}$ in the sense that it chooses the $\mathrm{n}$ which maximises a profit function given as:

$$
p=p f(n)-w n
$$

where $p$ is profit and $p$ is product price and $f(n)$ is a strictly concave production function. Thus the firm's labour demand is $n=g(w / p)$ with $g^{\prime}(w / p)<0$ and $g^{\prime \prime}(w / p)=0$ for linear labour demand. The effect on employment by an increase in product price is given by:

$\begin{aligned} & d n \\ & --\end{aligned}=\frac{g^{\prime}(w / p)}{---}[d w / d p-w / p]$

This means that if $d w / d p$ is negative than (6) is positive. Furthermore, it will be positive if the expression in the bracket is negative.

We now take the first part of the utility function where $w<w^{*}$. The union sets the wage rate (w) given labour demand. Thus the union's problem is:

$\underset{w}{\operatorname{Max}} \mathrm{U}=\quad \mathrm{wn}$

s.t 
$n=g(w / p)$

Applying the first order conditions, the following equation is the condition for a maximum:

$$
\begin{array}{ll}
w \\
-- \\
p
\end{array}=\begin{aligned}
& -g(w / p) \\
& ---- \\
& g^{\prime}(w / p)
\end{aligned}
$$

The above is the general specification of the model as far as the labour demand is concerned. Some authors have argued that it is more instructive (and also empirically more valid) to concentrate to a log-linear labour demand which is derived from a constant elasticity production function (see for instance, Jones and McKenna,1989). Thus in our next step, which is a comparative statics analysis, we adopt the log-linear labour demand. The constant elasticity form of production function is the following.

$\mathrm{f}(\mathrm{N})=\mathrm{Na} / \mathrm{a}, \quad$ where $\mathrm{a}<1$

this results in the following labour demand form::

$g(w / p)=(w / p)^{1 /(a-1)}$

By utilizing the first order condition and relation (10), the comparative static result for $\mathrm{w}^{\star}>\mathrm{w}$ is

$\begin{array}{ll}\mathrm{dw} \\ -- \\ \mathrm{dp} w<w^{*}\end{array}=\begin{aligned} & \mathrm{w} \\ & --\end{aligned}$

This is a very important result since it implies real wage rigidity. Combining the above with relation (6), we can see that $\mathrm{dN} / \mathrm{dp}=0$ for constant elasticity labour demand. Thus, as long 
as the wage level is below the target level, a positive shock (increase in $p$ ) will always result in real wage increases, or put it differently, there is real wage rigidity. This result is clearly a Keynesian one.

For the second part of the utility function $\left(w>w^{*}\right)$ we follow the same procedure. The union sets the wage subject to labour demand.

$\operatorname{Max} U=q\left(w-w^{*}\right) n+w^{*} n$

s.t

$n=g(w / p)$

Applying the first order conditions, the following equation is the condition for maximum:

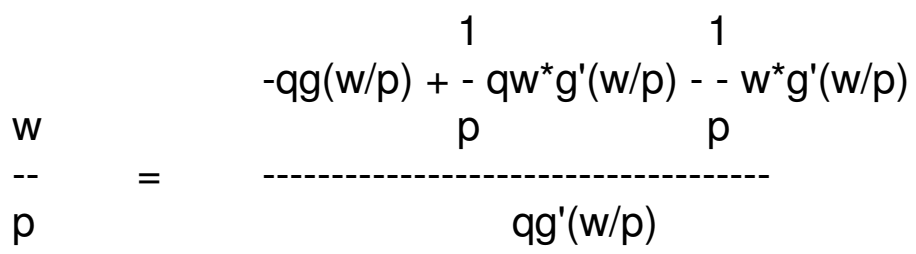

We concentrate on the constant elasticity production function and we follow exactly the same method as we did for the first part of the utility function. Having in mind the above, the comparative static result for $w>w^{*}$ is

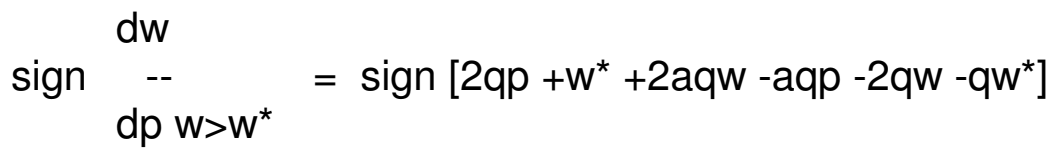

The sign of the above is ambiguous and clearly wage rigidity is not the case as it was for w $<\mathrm{w}^{\star}$. However, we can gain some insight by performing some simulations. Let us first take 
the extreme values of $q$ and $a$. The following table shows the sign of (15) assuming different combinations of extreme values. The table reports only the cases where the sign of $d w / d p$ is negative.

\section{Simulations of Extreme Values}

\begin{tabular}{cclc}
$a$ & $q$ & $w, p$ & Result \\
\hline 0 & Range & $w>p, w>>w^{*}$ & - \\
0 & 1 & $w>p$ & -
\end{tabular}

We can also do some actual simulations in the range of variables for different $w, w^{*}$ and $p$.

First Simulation: $p=5, w=10, w^{*}=9$.

If $a \geq 0.6$ then the sign is positive irrespective of the value of $q$. If $a<0.6$ and $q \leq 0.5$ the sign is positive. If $a<0.6$ and $q>0.6$ then the sign is negative in most cases (although not in all)

Second Simulation: $p=5, w=10, w^{*}=9$

If $a \geq 0.8$ the result is positive irrespective of the value of $q$. If $a<0.8$ and $q \leq 0.3$ then the sign is positive. However, if $a<0.8$ and $q>0.3$ then the sign is negative.

Third Simulation: $p=10, w=15, w^{*}=9$

All results are positive apart from the following simultaneous values for $a$ and $q: a=0.1$, $0.2,0.3$ and $q=0.6,0.7,0.8,0.9$.

Now it is clear that if $d w / d p$ for $w>w^{*}$ is negative, then $d n / d p$ is positive (if $d w / d p$ is positive, the sign of $d n / d p$ is ambiguous). 
With all the above in mind, it is possible to get possible wage paths. The interesting result here is that we derive kinked wage preference path. Relation (11) implies a vertical wage path up to $w^{*}$. For $w>w^{*}$ the expression $d w / d p$ might become negative or positive depending on the sign of relation 14. A possible wage path can be seen for negative sign.

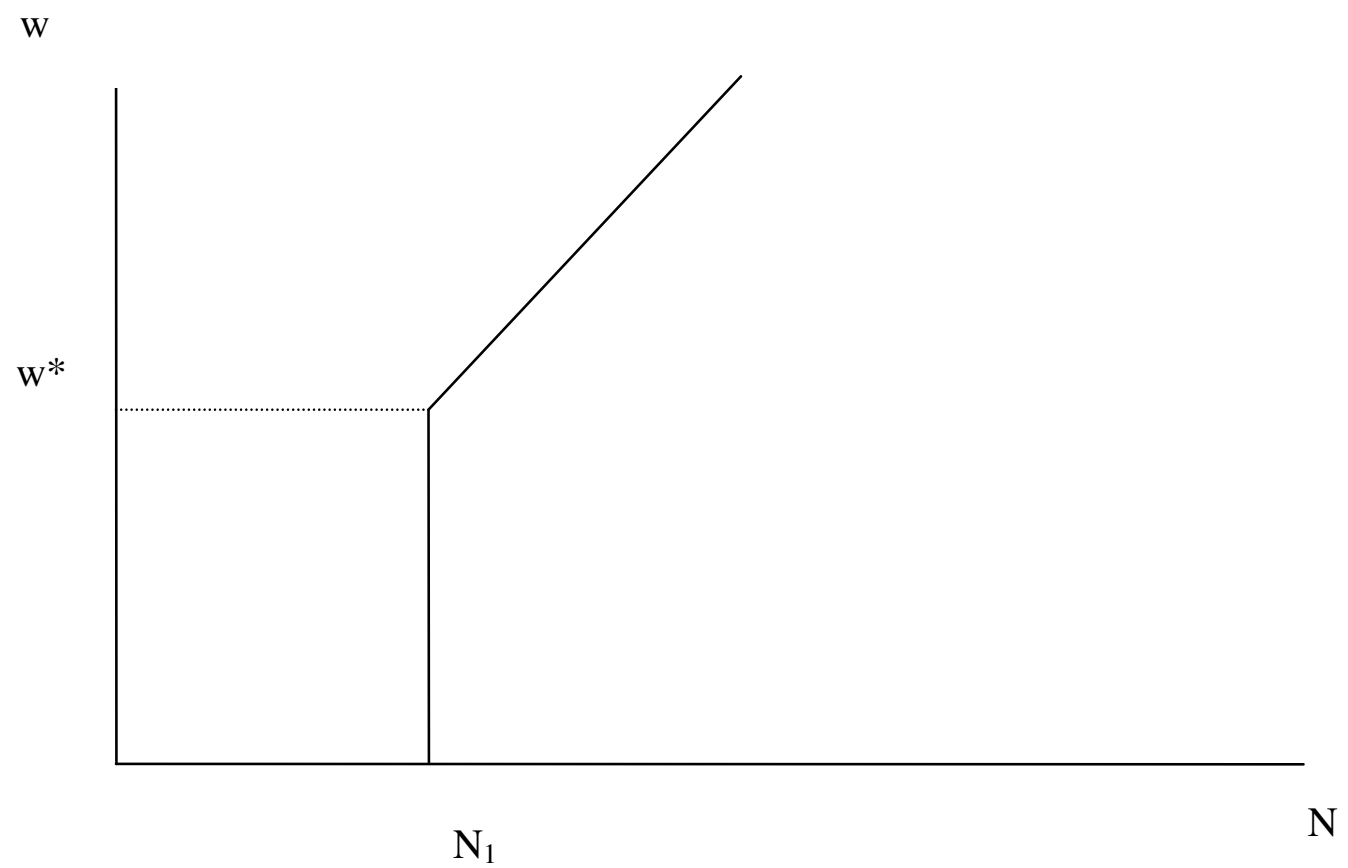

Figure 2: a possible wage path for constant elasticity labour demand

The graph implies that if there is a positive shock (i.e. there is an exogenous increase in 
product price $p$ ), the union will take it as wage increases only. However, after $\mathbf{w}^{*}$, there will be an increase in both wages and employment (the diagonal part of the graph).

The kinked wage preference path can be compared with the standard approach and also with the Cartter and Marshall model (Cartter, 1959 and Cartter and Marshall, 1967). Moreover, it can be seen as a justification to possible empirical findings which might suggest a kinked wage preference path.

The previous discussion has some interesting macroeconomic implications. First, there are no employment effects when the wage is below the target level since we have real wage rigidity. Second, since employment is likely to increase only when the wage rate is sufficiently high, a strong shock is needed in order to have significant effect on employment. However, the wage rate is likely to be sufficiently high in the boom stage of the business cycle. This could explain why employment increases significantly during a boom period (procyclical employment increase).

It would also be interesting to compare the macroeconomic implications with the possible ones derived under the traditional approach. First of all, the union indifference curves will be smooth since the traditional approach implies a single union utility function. This means that the wage path will not be kinked, -as in fig. 2- but it would be continuous. The important macroeconomic implication here is that positive shocks will only result in wage increases. This is in contrast to our results where employment increases after the target wage has been reached. Thus, in this framework, the traditional approach cannot offer an explanation for the commonly observed increases in employment during a boom period.

\section{Conclusion}

If we accept that the union is a complex organization with conflicting objectives and complicated social and economic roles, then the mainstream assumption of continuous 
substitutability among objectives might not be appropriate. Instead, the paper suggested that unions engage in substitution once certain targets have been met. This idea was connected to the writings of a number of theorists concerning the nature of the trade unions. Given these, the paper argued that a priority-based or hierarchical model might be a better approximation to union behaviour. Furthermore, the priority-based model might be more appropriate in countries where the degree of union centralization is relatively high. It was also shown that the priority-based model implies a two part union utility function which changes when a satisfactory level of the priority variable (i.e the wage rate) is met. The two-part union utility implies kinked union indifference curves, and this is in contrast to the smooth curves derived from the traditional approach.

Consequently, the paper demonstrated the workings of such a model in a monopoly union framework. It was seen that when the wage rate is below the target level, then there is real wage rigidity. Employment increases took place only when the target wage has been achieved. It is reasonable to assume that the wage rate is more likely to exceed the target during a boom period. Thus, the hierarchical trade union model might be an additional explanation to both real wage rigidity and to the fact that significant employment increases happen during a boom.

In general it is hoped that the paper will provide a stimulus for further research into the consequences of relaxing the mainstream assumption of continuous substitutability in relation to union behaviour for instance with respect to union bargaining and strikes. 


\section{REFERENCES}

Akerlof, G. (1969). Relative Wages and the Rate of Inflation, Quarterly Journal of Economics, 83, pp.353-74.

Ashenfelter, O. and Johns, G. (1969). Bargaining Theory, Trade Unions, and Industrial Strike Activity", American Economic Review LIX, pp.35-49.

Atherton, W. (1973). Theory of Union Bargaining Goals, Princeton : Princeton University Press.

Borch, K. (1968). The Economics of Uncertainty, Princeton : Princeton University Press.

Calmfors, L. and Driffill, J. (1988). Bargaining structure, Corporatism and Macroeconomic Performance, Economic Policy, 6, pp.13-62.

Canterbery, R. (1979). Inflation Necessities and Distributive Efficiency, in J. Gapinski and C. Rockwood, Essays in Post-Keynesian Inflation, Cambridge Mass.: Ballinger.

Carruth, A. and Oswald, A. (1987). On Union Preferences and Labour Market Models: Insiders and Outsiders The Economic Journal, 97, pp.431-45.

Cartter, A. (1959). Theory of Wages and Employment, Homewood: Irwin.

Cartter, A. and Marshall, R. (1967). Labor Economics : Wages, Employment and Trade Unionism, Homewood : Irwin.

Corden, W. (1981). Taxation, Real Wage Rigidity and Employment, Economic Journal, 91, pp.309-30.

Day, R. and Robinson, S. (1973). Economic Decision and L** Utility, in J. Cochrane and M. Zeleny, Multiple Criteria Decision Making, Columbia : University of Southern Carolina Press.

Drakopoulos, S. (1992). Psychological Thresholds, Demand and Price Rigidity, Manchester School, LX pp.152-68.

Dreze, J. (1987). Work Sharing : Why? How? How Not... in R. Layard and L. Calmfors (eds) The Fight Against Unemployment, Cambridge Mass.: MIT Press.

Earl, P. (1983). The Economic Imagination, Brighton : Wheatsheaf Books.

Encarnacion. J. (1964a). A Note on Lexicographical Preferences, Econometrica, vol.32, pp.215-217.

Encarnacion. J. (1964b). Constraints and the Firm's Utility Function, Review of Economic Studies, vol.16, pp.113-119.

Ferguson, C. (1965). The Theory of Multidimensional Utility Analysis in Relation to 
Multiple-Goals Business Behaviour : A Synthesis, Southern Economic Journal, Vol. 32, pp.169-75.

Flanagan, R., Moene, K. and Wallerstein, M. (1993). Trade Union Behaviour, PayBargaining, and Economic Performance, Oxford: Clarendon Press.

Georgescu-Roegen, N. (1966). Analytical Economics, Cambridge : Cambridge University Press.

Ironmonger, D. (1972). New Commodities and Consumer Behaviour, Cambridge : Cambridge University Press.

Johnston, J. (1972). A Model of Wage Determination Under Bilateral Monopoly, Economic Journal, vol.82, pp.837-52.

Jones, S. and McKenna, C. (1989). The Effect of Outsiders on Union Contracts, European Economic Review, 33, pp.1567-73.

King, J. (1990). Labour Economics, London : Macmillan.

Little, I.M.D. (1957). A Critique of Welfare Economics, Oxford : Clarendon Press.

McCurdy, T. and Pencavel, J. (1986). Testing Between Competing Models of Wage and Employment Determination in Unionized Markets, Journal of Political Economy, 94, pp.3039.

Maslow, A. (1954) Motivation and Personality, New York: Harper and Row.

Mayhew, K. And Turnbull, P. (1989). Models of Union Behaviour : A Critique of Recent Literature, in R. Drago and R. Perlman (eds) Microeconomic Issues in Labour Economics, London : Harvester Wheatsheaf.

McDonald, I. and Solow, R. (1981). Wage Bargaining and Employment, American Economic Review, 71, pp.896-908.

Mulvey, C. (1978). The Economic Analysis of Trade Unions, Oxford; Martin Robertson.

Oswald, A. (1982). The Microeconomic Theory of the Trade Union, Economic Journal, vol.92, pp.576-95.

Oswald, A. (1985). The Economic Theory of Trade Unions; an Introductory Survey, Scandinavian Journal of Economics, vol.87, pp.160-93.

Reder, M. (1952). The Theory of Trade Union Wage Policy, Review of Economics and Statistics, vol.34, pp.34-45.

Reder, M. (1960). Job Scarcity and the Nature of Union Power, Industrial and Labor Relations Review, 13, pp.349-362.

Rees, A. 91977). The Economics of Trade Unions, Chicago : University of Chicago Press. 
Ross, A. (1948). Trade Union Wage Policy in E. McCarthy, 1972, (ed), Trade Unions, Harmondsworth : Penguin.

Ross, A. (1950). The Tie between Wages and Employment, Industrial and Labor Relations Review, vol.4, pp.99-101.

Simon, H. (1982). Models of Bounded Rationality, Cambridge Mass.: MIT Press.

Shultz, G. and Myers, C. (1950). Union Wage Decisions and Employment, American Economic Review, XL, pp.362-380.

Summers, L. (1988). Relative Wages, Efficiency Wages, and Keynesian Unemployment, American Economic Review, Papers and Proceedings, 78, pp.383-88.

Swint, M. and Nelson, W. (1978). The Influence of Negotiators' Self-Interest on the Duration of Strikes, Industrial and Labor Relations Review, 32, pp.56-66.

Swint, M. and Nelson. W. (1980). Self-Motivated Bargaining and Rational Strikes : a Multiparty Model and its Implications for Industrial Strike Activity, Southern Economic Journal 47, pp.317-31.

Turnbull, P. (1988). The Economic Theory of Trade Union Behaviour: a Critique, British Journal of Industrial Relations, vol.25, pp.99-118. 